\title{
TNF- $\alpha$ mediated NF-kappaB activation is constantly extended by transglutaminase 2
}

\author{
Kang-Seo Park ${ }^{1,4}$, Dae-Seok Kim ${ }^{1}$, Chunkyu Ko ${ }^{1}$, Sang-Jin Lee ${ }^{2}$, Seung Hyun $\mathrm{Oh}^{3}$, Soo-Youl Kim ${ }^{1}$ \\ ${ }^{I}$ Cancer Cell and Molecular Biology Branch, Goyang, Gyeonggi-do 410-769, Republic of Korea, ${ }^{2}$ Genitourinary Cancer Branch, \\ Division of Translational and Clinical Research II, National Cancer Center, Goyang, Gyeonggi-do 410-769, Republic of Korea, \\ ${ }^{3}$ Carcinogenesis Branch, Division of Cancer Biology, Goyang, Gyeonggi-do 410-769, Republic of Korea, ${ }^{4}$ Department of \\ Biomedical Science, Graduate School, Kyung Hee University, Seoul 130-701, Republic of Korea
}

\section{TABLE OF CONTENTS}

1. Abstract

2. Introduction

3.. Materials and methods 3.1. Western blotting

3.2. Plasmid constructs and transient transfection

3.3. Reporter assay: SEAP assay, $\beta$-galactosidase assay and $\beta$-lactamase assay

3.4. Immunocytochemical analysis

3.5. Adenovirus construction expressing TGase 2

3.6. In vivo animal experiments

4. Results

3.7. Electrophoretic mobility shift assay for the detection of nuclear $N F-\kappa B$

4.1. TGase 2 and TNF- $\alpha$ mediated $N F-\kappa B$ activation and its reducing by cystamine, TGase 2 inhibitor

4.2. Role of TGase 2 on I- $\kappa B \alpha$ degradation in $T N F$ - $\alpha$ induced $N F-\kappa B$ signaling pathway

4.3. The elongate effect of TGase 2 on maintenance of $T N F-\alpha$ mediated $N F-\kappa B$ activation

4.4. Inhibitory effect of TNF- $\alpha$ induced $N F-\kappa B$ activation by $I-\kappa B \alpha$ mutation at TGase 2 targeting sites

4.5. Reduction of TNF- $\alpha$ induced $N F-\kappa B$ translocation to nucleus with $I-\kappa B \alpha$ mutants at TGase 2 targeting sites

5. Discussion

4.6. Profound $N F-\kappa B$ activation in mouse liver by TNF- $\alpha$ injection together with TGase 2 over-expression

5.1. TGase 2 expression is increased in inflammatory diseases and cancers

5.2. The prolongation effect of TGase 2 on TNF- $\alpha$-induced $N F-\kappa B$ activation

5.3. Reduction of TNF- $\alpha$ induced $N F-\kappa B$ activation by TGase 2 inhibition

5.4. Exacerbation of TNF- $\alpha$-mediated inflammation in the mouse liver by TGase 2 over-expression

5.5. Model for TGase 2 in $N F-\kappa B$ activation

6. Acknowledgments

7. References

\section{ABSTRACT}

Increased levels of transglutaminase 2 (TGase 2) expression have been reported in many inflammatory diseases, as well as in drug resistant cancer cells. Previous reports have shown that TGase 2 is capable of inducing nuclear factor-kappaB (NF-kappaB) activation via depletion of inhibitor of kappaB (I-kappaB) $\alpha$ through polymerization in the absence of I-kappaBalpha kinase activation. This raises the question of whether increased expression of TGase 2 can extend NF-kappaB activation mediated by a canonical activation pathway. In the TGase 2-inducible EcR23/TG cell line, TGase 2 over-expression resulted in sustained activation of NF- $\mathrm{KB}$ in the presence of TNF-alpha, for up to $24 \mathrm{hrs,} \mathrm{while} \mathrm{in} \mathrm{the} \mathrm{absence} \mathrm{of} \mathrm{TGase}$ 2 induction, NF-kappaB activity was restored to basal levels within $6 \mathrm{hrs}$ of TNF-alpha treatment. In mice injected with an adenovirus vector expressing TGase 2, NF-kappaB was constitutively activated for up to 5 days, whereas Adeno/GFP-injected mice exhibited attenuated activation of NF-kappaB in response to TNF- $\alpha$ stress. Thus, the presence of increased levels of TGase 2 may exacerbate $\mathrm{NF}-\kappa \mathrm{B}$ activation in inflammatory states.

\section{INTRODUCION}

Constitutive activation of nuclear factor- $\kappa \mathrm{B}(\mathrm{NF}-\kappa \mathrm{B})$ is essential for chronic inflammation (1) as well as cancer progression (2). Tremendous effort has led to our current understanding of the mechanisms of activation of NF- $\mathrm{\kappa B}$ by various inducers. NF- $\mathrm{KB}$ is activated by biological stress such as bacterial infection (3), physical stress such as UV radiation (4), and chemical stresses such as reactive oxygen intermediates (5) and tumor necrosis factor (TNF)- $\alpha$-activated signaling pathways (6). Mutations that result in constitutive activation of NF- $\kappa B$ have been reported in certain cancers (1). However, in many types of inflammatory diseases and cancers, $\mathrm{NF}-\kappa \mathrm{B}$ activation is achieved in the absence of constitutive I$\kappa \mathrm{B} \alpha$ phosphorylation $(7,8,3)$. Even under physiological conditions, a single inducer such as TNF- $\alpha$ demonstrates bimodal signaling kinetics, leading to prolongation of stimulus duration (9). These results suggest that there are intrinsic factors in cells that mediate stable long-term responsiveness to a single $\mathrm{NF}-\kappa \mathrm{B}$ inducer.

Inflammation induces the expression of hundreds of genes and alters the physiological responses of cells. A 
very complex sequence of gene expression is involved in chronic inflammation in various disease states. One of these intrinsic factors is transglutaminase 2 (TGase 2, E.C. 2.3.2.13). TGase 2 is a calcium-dependent cross-linking enzyme that catalyzes the formation of iso-peptide bonds between glutamines and lysines within proteins $(10,11)$. Increased levels of TGase 2 expression have been reported in autoimmune diseases such as inflammatory myopathies $(12,13)$ and Celiac disease (14). Increased TGase 2 expression has also has been reported in many inflammatory diseases such as rheumatoid arthritis (15), Simian immunodeficiency virus (SIV) encephalitis (16), and allergic conjunctivitis (17). Additionally, deregulation of TGase 2 expression has been reported in some cancers such as lung cancer (18), breast cancer (11, 19), hepatoblastoma (20), pancreatic cancer (21) and glioblastoma (22). TNF- $\alpha$ expression is upregulated in early hepatic inflammation, and Kuncio et al showed that treatment of liver cells with TNF- $\alpha$ results in upregulation of TGase 2 expression (23). However, the precise role of TGase 2 in inflammation is largely unknown, although it has been suggested that TGase 2 activates phospholipase A2 $\left(\mathrm{PLA}_{2}\right)$ via intracrosslinking $(17,24)$. Recently, we demonstrated that TGase 2 is able to activate $N F-\kappa B$ in the absence of inhibitor of $\mathrm{I}-\kappa \mathrm{B}$ (IKK)-pathway activation in rat neuroblastoma, mouse microglia, human kidney and human breast cancer cells $(10,11)$. One possible mechanism is the depletion of free inhibitor of $\kappa \mathrm{B}$ (I$\kappa B) \alpha$ by TGase 2 through polymerization of lysines 22

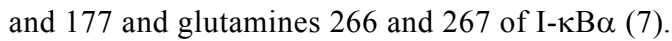

Constitutively elevated TGase 2 expression has been observed in inflammatory diseases as well as in some types of cancer. Interestingly, various NF- $\mathrm{BB}$ inducers, including physical, biological, and chemical stresses, are also able to induce TGase 2 (11). We have demonstrated that TGase 2 inhibition markedly reduces inflammatory processes in several inflammatory disease models, including pollen-induced allergic conjunctivitis (17), an LPS-induced brain injury model (25), and an LPS-induced lung injury model (26). In cancer models such as malignant glioblastoma (27) and drug resistant breast cancer (28), TGase 2 inhibition also markedly increases drug sensitivity through down regulation of NF- $\kappa$ B activity (25).

The aim of the current study was to determine whether increased TGase 2 expression activates NF-kB simultaneously and in a cooperative manner with one of the canonical pathways of NF- $\kappa \mathrm{B}$ activation, TNF- $\alpha$. To test this, we used an in vitro cell culture system in which TGase 2 expression is induced by tetracycline, and an in vivo system of recombinant adenovirus vector-mediated overexpression of TGase 2 in mice. In both systems, TNF- $\alpha$ treatment in combination with TGase 2 over-expression resulted in a profound increase of NF- $\kappa \mathrm{B}$ activity that was sustained for over $72 \mathrm{hrs}$, while in control groups, activity recovered to basal levels within $24 \mathrm{hrs}$. The results of the current study provide compelling evidence that increased TGase 2 expression levels play an important role in constitutive NF- $\kappa \mathrm{B}$ activation.

\section{MATERIALS AND METHODS}

\subsection{Immunoblot analysis}

Cytosolic fractions were prepared using a CelLytic NuCLEAR Extraction kit (Sigma) according to the manufacturer's instructions. Samples were subjected to electrophoresis on a NuPAGE 4-12\% Bis-Tris gel in MOPS SDS running buffer (Invitrogen) and then transferred to a polyvinylidene difluoride membrane (Bio-Rad) using a semidry blotting apparatus (Hoefer SemiPhor). Membranes were incubated in Tris-buffered saline containing $0.5 \%$ Tween 20 (TBS-T) and 5\% bovine serum albumin (BSA) for $1 \mathrm{hr}$ at room temperature and then incubated with primary antibody overnight at $4^{\circ} \mathrm{C}$. The primary antibodies used in these studies were as follows: anti-I- $\kappa \mathrm{B}-\alpha$ (Cell Signaling Technologies), anti-TGase 2 (clone CUB 7402,

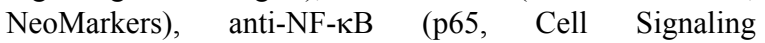
Technologies) and anti- $\beta$-actin (Abcam). After incubation with primary antibody, the membrane was washed 3 times for 20 minutes (min) each in TBS-T and then incubated with horseradish peroxidase (HRP)-conjugated secondary antibody (Bio-Rad) in TBS-T containing 1\% BSA for $1 \mathrm{hr}$ at room temperature. The concentration of primary and secondary antibody was 3.0 and $0.1 \mu \mathrm{g} / \mathrm{ml}$, respectively. Immunoreactive proteins were visualized using enhanced chemi-luminescence (Pierce).

\subsection{Plasmid Constructs and Transient Transfection}

Single point mutations in full-length $\mathrm{I}-\kappa \mathrm{B} \alpha$ (K177G, Q255G, Q266G, Q267G, K21G/22G, S32A/36A) were constructed by the recombinant PCR method using the full-length I- $\kappa \mathrm{B} \alpha \mathrm{cDNA}$ as a template (pCMV- I- $\kappa \mathrm{B} \alpha$; $\mathrm{BD}$ Biosciences). Amplified fragments containing point mutations were inserted into pcDNA 3.0 (Invitrogen) at the Hind III and Xba I sites. The sequences of the clones were verified by DNA sequencing. Transient transfection with wild type $(1 \mu \mathrm{g})$ or mutant I- $\kappa \mathrm{B} \alpha(1 \mu \mathrm{g})$ expression vectors and/or pcDNA-hTG2, or pcDNA 3.0 (Invitrogen) as a control (mock vector), was carried out using lipofectamin $^{\mathrm{TM}} 2000$ (Invitrogen) according to the manufacturer's instructions. Briefly, cells were seeded at a density of $4 \times 10^{5}$ cells/well in a 6 -well plate. When cells reached $40-50 \%$ confluence they were washed with $2 \mathrm{ml}$ of Opti-MEM (Invitrogen) and then incubated with DNAlipofectamine mixture $(1 \mu \mathrm{g}$ of DNA plus $3 \mu \mathrm{l}$ of lipofectamine reagent) for $6 \mathrm{hrs}$ in a humidified $5 \% \mathrm{CO}_{2}$ chamber. The medium was replaced with fresh culture medium and the cells were allowed to incubate for an additional 48 hrs. For the secreted alkaline phosphatase (SEAP) reporter assay, cells were transfected with a reporter plasmid in which expression was driven by the

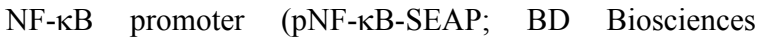
Clontech, $1.0 \mu \mathrm{g}$ ) using $3 \mu \mathrm{l}$ of Lipofectamine 2000. Cells were co-transfected with pGAL $(1.0 \mu \mathrm{g})$ to normalize for transfection efficiency. Transfection of a small interfering RNA (siRNA) duplex targeting human TGase 2 (5'AAGAGCGAGAUGAUCUGGAAC-3') was carried out using Lipofectamine RNAiMAX (Invitrogen), according to the manufacturer's instructions. Briefly, cells were seeded at a density of $3 \times 10^{5}$ cells/well in a 6-well tissue culture dish and then incubated overnight. Cells were transfected 
with siRNA-Lipofectamine mixture (200 pmol siRNA and $3 \mu$ of Lipofectamine reagent) and then allowed to incubate for 2 days. Transfection complexes were removed and then the cells were incubated in culture medium without antibiotics in preparation for TNF- $\alpha$ treatment. As a control, cells were incubated with the Lipofectamine RNAiMAX Stealth Negative control (Invitrogen).

\subsection{Reporter Assays: SEAP Assay, $\beta$-galactosidase} Assay, and $\beta$-lactamase Assay

$N F-\kappa B$ activity was measured using the SEAP reporter system 3 (BD Bioscience Clontech). Cell culture medium was collected 24-48 hours after transfection with pNF- $\kappa B-S E A P$. The SEAP assay was performed according to the manufacturer's instructions. Briefly, culture medium $(25 \mu \mathrm{L})$ was mixed with $25 \mu \mathrm{L}$ of dilution buffer in a 96well flat-bottomed microtiter plate and then incubated at $65^{\circ} \mathrm{C}$ for $30 \mathrm{~min}$. The plate was chilled on ice for 2 minutes, after which $97 \mu \mathrm{L}$ of assay buffer was added to each well. The plates were incubated at room temperature for $5 \mathrm{~min}$, followed by the addition of $3 \mu \mathrm{L}$ of $1 \mathrm{mM}$ MUP fluorescent substrate, and then the plates were incubated for an additional $60 \mathrm{~min}$ in the dark at room temperature. The fluorescence of each sample was measured using a 96-well fluorescent plate reader (SpectraMAX GeminiEM, Molecular Devices) equipped with a $360-\mathrm{nm}$ wavelength excitation filter and a 460-nm wavelength emission filter. To normalize for expression levels in cells transfected with various expression plasmids, cells were co-transfected with pGAL $(1 \mu \mathrm{g})$. SEAP activity was normalized to $\beta$ galactosidase activity. The $\beta$-galactosidase assay was performed using a $\beta$-Galactosidase Enzyme Assay System (E2000, Promega) (Figs. 1 and 3). To determine NF-kB activity, we used the HEK293T/NF-kB-bla cell system, a live cell reporter assay. The $\beta$-lactamase assay was carried out using a $\beta$-lactamase loading kit and the CCF4-AM substrate (K1096, Invitrogen), according to the manufacturer's instructions (Figs. 3 and 4). Results represent the averages and standard deviation (SD) of three independent experiments.

\subsection{Immunocytochemical Analysis}

The translocation of p65 was visualized by immunostaining and confocal microscopy as described previously (Kim, 2006). EcR293/TG cells were seeded in a two-well slide chamber $\left(1 \times 10^{5}\right.$ cells per well $)$ and then transfected with mutant I- $\kappa \mathrm{B} \alpha(\mathrm{K} 177 \mathrm{G}, \mathrm{Q} 266 \mathrm{G}, \mathrm{Q} 255 \mathrm{G})$ or wild-type (WT) I- $\kappa \mathrm{B} \alpha$ expression constructs, as indicated, for $24 \mathrm{hrs}$. The cells were treated with tetracycline $(1 \mu \mathrm{g} / \mathrm{ml})$ for $24 \mathrm{hrs}$ to induce TGase 2 expression, after which they were treated with TNF- $\alpha(100$ $\mathrm{ng} / \mathrm{ml}$ ) for $2 \mathrm{hrs}$. Cells were incubated in $3.7 \%$ paraformaldehyde on ice for $15 \mathrm{~min}$ and then washed with $0.1 \%$ PBS-T. Cells were permeabilized with $0.5 \%$ PBS-T for 5 minutes, washed again in $0.1 \%$ PBS-T, incubated for $1 \mathrm{hr}$ in PBS containing $10 \%$ calf serum and $0.5 \%$ gelatin, and finally washed with $0.1 \%$ PBS-T. Fixed cells were incubated with mouse monoclonal anti-p65 antibody (1:100 dilution, Santa Cruz Biotechnology) for $1 \mathrm{hr}$ at room temperature, washed with $0.1 \%$ PBS-T, and then incubated with a fluorescent isothiocynate-conjugated anti-mouse IgG
(1:200 dilution, Jackson ImmunoResearch Labs) for $1 \mathrm{hr}$ at room temperature. The cells were washed with $0.1 \%$ PBS$\mathrm{T}$, incubated with 4,6-diamindino-2-phenylindole (DAPI, Sigma) nuclear dye for $5 \mathrm{~min}$ at room temperature, washed with $0.1 \%$ PBS-T again, and then mounted using VectaShield (Vector Laboratories). NF- $\kappa \mathrm{B}$ expression was visualized using a Zeiss axiovert LSM510 microscope.

\subsection{Construction of an Adenovirus vector Expressing} TGase 2

The recombinant adenovirus expressing TGase 2 was constructed by insertion of the full-length TGase 2 cDNA into the adenoviral shuttle vector pAd1020SfidA $\left(\mathrm{OD}_{260}\right.$, Inc., Boise, ID, USA). Briefly, a fragment containing CMV-multiple cloning sites-pA-CMV-GFP-pA was excised from pAdTrack-CMV (a generous gift from Dr. Bert Vogelstein) and then inserted into pAd1020SfidA to create pAdSfidACMVGFP. The full-length TGase 2 cDNA was cloned into the EcoRI/SalI sites of pAd1020sfidACMVGFP (pAd1020CMV GFP-CMVTG2), and then this construct was digested with SfiI and PacI and the resulting fragment was ligated into AdenoZap1.2 $\left(\mathrm{OD}_{260}\right)$. HEK293 cells were transfected with the adenoviral vector using Lipofectamine 2000 (Invitrogen). Amplified adenoviruses expressing TGase 2 (Adeno/TG2) were purified by $\mathrm{CsCl}$ gradient centrifugation, dialyzed against $1 \mathrm{~L}$ of dialysis buffer $(789 \mathrm{ml}$ of double-distilled water, $1 \mathrm{ml}$ of $1 \mathrm{~mol} / \mathrm{L} \mathrm{MgCl}_{2}, 10 \mathrm{ml}$ of $1 \mathrm{~mol} / \mathrm{L}$ Tris- $\mathrm{HCl}$ (pH 7.5) and $200 \mathrm{ml}$ of $50 \%$ glycerol) for $24 \mathrm{hrs}$ at $4^{\circ} \mathrm{C}$ with three buffer changes and then stored at $-80{ }^{\circ} \mathrm{C}$ for future use.

\subsection{Animal Experiments}

Six-week-old BALB/c mice were housed in the animal facilities of the National Cancer Center and cared for in accordance with the Declaration of Helsinki and the National Institutes of Health Guide for the Care and Use of Laboratory Animals. Mice were injected with $1.0 \times 10^{9}$ virus particles of Adeno/TG2, or AdCMVGFP as a control, via tail vein injection using a 34-gauge Hamilton syringe (Hamilton). Twenty-four hrs after viral injection, $0.5 \mu \mathrm{g} / \mathrm{g}$ of body weight of TNF- $\alpha$ (R\&D Systems Inc) was injected via the tail vein. Five mice were sacrificed $120 \mathrm{hrs}$ after TNF- $\alpha$ injection.

\subsection{Electrophoretic Mobility Shift Assay for the detection of nuclear NF- $\mathrm{\kappa B}$ \\ Nuclear extracts were prepared using a CelLytic ${ }^{\mathrm{TM}}$} NuCLEAR ${ }^{\mathrm{TM}}$ Extraction kit (Sigma). An NF- $\kappa \mathrm{B}$ doublestranded oligonucleotide (5'-AGT TGA GGG GAC TTT CCC AGG C-3') was purchased from Santa Cruz Biotechnology and used as the probe. The DNA probe was labeled with Redivue adenosine 5 ' $-\left(\gamma-{ }^{32} \mathrm{P}\right)$ triphosphate, Triethylammonium salt (Amersham AA0068; $9.25 \mathrm{MBq}$, $250 \mu \mathrm{Ci}, 10 \mu \mathrm{Ci} / \mu \mathrm{l} / 25 \mu \mathrm{l}$ ) using $\mathrm{T} 4$ kinase (Takara) and T4 kinase buffer (10X); radiolabeled probe was purified using MicroSpin G-25 columns (Amersham, 27-5325-01). Labeled probe was incubated with nuclear extracts for 20 $\min$ at $37^{\circ} \mathrm{C}$. The mixtures were separated on a $6 \%$ nondenaturing polyacrylamide gel. The gel was exposed to a BAS-MS2040 plate (FUJIFILM) for $30 \mathrm{~min}$ in a BAS cassette2 (FUJIFILM). Signals were detected using a BAS- 
2500 Phosphor Imager (FUJIFILM).

\section{RESULTS}

4.1. TGase 2- and TNF- $\alpha$-mediated NF- $\kappa B$ activation is reduced by the TGase 2 inhibitor cystamine

To determine whether TGase 2 expression modulated the activation of NF- $\kappa$ B via the canonical TNF-a pathway, we carried out a SEAP gene reporter assay using the TGase 2-inducible cell line EcR293, in which the expression of TGase 2 is induced by tetracycline (Kim, 2006; Lee et al., 2004). Upon tetracycline stimulation, TGase 2 levels increased concomitantly with a decrease in $\mathrm{I}-\kappa \mathrm{B} \alpha$ protein levels, as assessed by immunoblot analysis (Figure 1B). This decrease in I- $\kappa \mathrm{B} \alpha$ levels was also evident as an increase in NF- $\kappa \mathrm{B}$ promoter activity (Figure 1A). To determine whether TGase 2 inhibition reversed the prolongation of NF- $\kappa$ B activation, EcR293/TG cells were treated with the TGase 2 inhibitor cystamine (CTM) (Figure 1). Following treatment of cells with varying concentrations of CTM $(0.5,1,5 \mathrm{mM})$ for $1 \mathrm{hr}$, TGase 2 was induced by treatment with tetracycline for $18 \mathrm{hrs}$, followed by TNF- $\alpha$ treatment for $6 \mathrm{hrs}$ in the presence or absence of CTM. Induction of TGase 2 expression increased NF- $\mathrm{KB}$ activity approximately $50 \%$, whereas TNF- $\alpha$ treatment resulted in maximal activation of NF- $\kappa B$ (Figure 1). Induction of TGase 2 expression resulted in constitutive (prolonged) activation of NF- $\mathrm{B}$ activity by TNF- $\alpha$ (Figure 1). Furthermore, NF- $\kappa B$ activity was reduced by the TGase 2 inhibitor CTM in a dose dependent manner (Figure 1). Immunoblot analysis showed that I$\kappa \mathrm{B} \alpha$ levels were also restored by CTM treatment in TGase 2-induced cells in a dose dependent manner (Figure 1). Thus, I- $\kappa \mathrm{B} \alpha$ levels decreased in the presence of TNF- $\alpha$, and this decrease was rescued to a certain extent by CTM. These results suggested that TGase 2 prolongs NF- $\kappa B$ activation by TNF- $\alpha$. Then, we treated TNF- $\alpha$ for $24 \mathrm{hrs}$ instead of $6 \mathrm{hrs}$.

4.2. Effect of TGase 2 expression on $I-\kappa B \alpha$ degradation induced by TNF- $\alpha$ treatment and activation of NF- $\kappa B$ signaling pathways

In cells in which TGase 2 expression was induced, NF- $\kappa \mathrm{B}$ activity was constitutively increased in the presence of TNF- $\alpha$. To determine whether this increase in $\mathrm{NF}-\kappa \mathrm{B}$ activity in the presence of TGase 2 was due to decreased I- $\kappa$ B $\alpha$ levels, EcR293/TG cells were treated with TNF- $\alpha$ with or without induction of TGase 2 for 24 hrs, and then TGase 2 and I- $\kappa \mathrm{B} \alpha$ protein levels were analyzed by immunoblot (Figure $2 \mathrm{~A}$ ). In the absence of TGase 2 induction, $\mathrm{I}-\mathrm{\kappa} \mathrm{B} \alpha$ levels almost completely recovered within $6 \mathrm{hrs}$ of TNF- $\alpha$ treatment (Figure 2A). In cells in which TGase expression was induced, I- $\kappa \mathrm{B} \alpha$ protein levels failed to recover, even after $24 \mathrm{hrs}$ of TNF- $\alpha$ treatment (Figure 2A). We previously reported that in MCF7/DOX cells (doxorubicin-resistance MCF-7 cells), TGase 2 expression is constitutively elevated as compared to MCF-7 cells (Figure 2B) (11). In MCF-7 cells, I- $\kappa \mathrm{B} \alpha$ levels recovered within 6 hrs of TNF- $\alpha$ treatment, whereas in MCF7/DOX cells, the levels of I- $\kappa \mathrm{B} \alpha$ remained low even after $24 \mathrm{hrs}$ of
TNF- $\alpha$ treatment (Figure 2B). To determine the effect of TGase 2 down-regulation on I- $\kappa \mathrm{B} \alpha$ levels in MCF7/DOX cells, cells were treated with a TGase 2 siRNA for 2 days. The recovery of I- $\kappa \mathrm{B} \alpha$ levels in TGase 2 siRNA-treated MCF/DOX cells reached that of MCF-7 cells within $6 \mathrm{hrs}$ of TNF- $\alpha$ treatment (Figure 2C).

\subsection{TGase 2 sustains TNF- $\alpha$ mediated NF- $\kappa B$ activation}

To determine the kinetics of NF- $\kappa \mathrm{B}$ activation by

TNF- $\alpha$ in the presence or absence of TGase 2 expression, we assayed a panel of cell lines (EcR293/TG, MCF-7, MCF/DOX, HEK293T/NF-кB-bla) containing varying levels of TGase 1 (Figure 3). Cells were transfected with pNF-кB-SEAP (and a TGase 2 expression vector, where indicated), and then NF- $\kappa \mathrm{B}$ activity was measured by the SEAP gene reporter assay. Dual activation of NF- $\kappa B$ by TGase 2 and TNF- $\alpha$ resulted in a high level of sustained activity as compared to TNF- $\alpha$ alone (Figure 3 A-C). Down-regulation of TGase 2 in MCF7/DOX cells by siRNA treatment shortened the period of sustained NF- $\mathrm{KB}$ activation as compared to mock treated MCF7/DOX cells (Figure $3 \mathrm{C}$ ). These results indicated that TGase 2 plays an important role in the sustained pattern of NF- $\mathrm{KB}$ activation observed in many inflammatory diseases.

\subsection{Inhibition of $T N F-\alpha-i n d u c e d ~ N F-\kappa B$ activation by expression of TGase 2 targeting site mutants of $I-\kappa B \alpha$}

To investigate the mechanism by which TGase 2 modulated TNF- $\alpha$-mediated NF- $\kappa \mathrm{B}$ activation, we generated a set of dominant negative mutant forms of I$\kappa \mathrm{B} \alpha$ containing single point mutations in ubiquitination sites (K21/22), IKK phosphorylation sites (S32/36), or TGase 2 cross-linking sites (K177, Q267), as well as a randomly mutated negative control (Q255). HEK293T/NF$\kappa \mathrm{B}$-bla cells were co-transfected with wild-type or mutant $\mathrm{I}-\kappa \mathrm{B} \alpha$ and TGase 2 expression vectors for $48 \mathrm{hrs}$, and then $\mathrm{NF}-\kappa \mathrm{B}$ activity was measured by $\beta$-lactamase reporter assay (Figure 4). NF- $\kappa B$ activity was measured after $6 \mathrm{hrs}$ of TNF- $\alpha$ treatment. I- $\kappa \mathrm{B} \alpha$ ubiquitination site mutants and IKK phosphorylation site mutants reduced NF- $\kappa \mathrm{B}$ activation by approximately $50 \%$ and $40 \%$, respectively (Figure 4A). Mutants containing single amino acid substitutions in the TGase 2 targeting sites (K177 and Q267) reduced NF- $\mathrm{B}$ activity by $60 \%$ (Figure $4 \mathrm{~A}$ ). Immunoblot analysis confirmed that $\mathrm{I}-\kappa \mathrm{B} \alpha$ levels were decreased in the presence of the control mutant (Q255) as compared to the dominant negative mutants of $\mathrm{I}-\mathrm{\kappa B} \alpha$ (K21/22, S32/36, K177, Q266, Q267) (Figure 4B).

\subsection{Nuclear Translocation of $N F-\kappa B$ in response to TNF- $\alpha$ is impaired by TGase 2 targeting site mutants of $\mathbf{I}-\mathbf{k B} \alpha$}

To examine whether inhibition of TGase 2 affected the translocation of NF- $\kappa \mathrm{B}$ into the nucleus in response to TNF- $\alpha$, EcR293/TG cells were transfected with expression vectors for wild-type $I-\kappa B \alpha$ or the various $I-\kappa B \alpha$ mutants for $24 \mathrm{hrs}$ and then TGase 2 was induced for $12 \mathrm{hrs}$, followed by treatment with or without TNF- $\alpha$ for $2 \mathrm{hrs}$. Localization of NF- $\kappa B$ was analyzed by immunocytochemistry using an anti-p65 antibody (Figure 

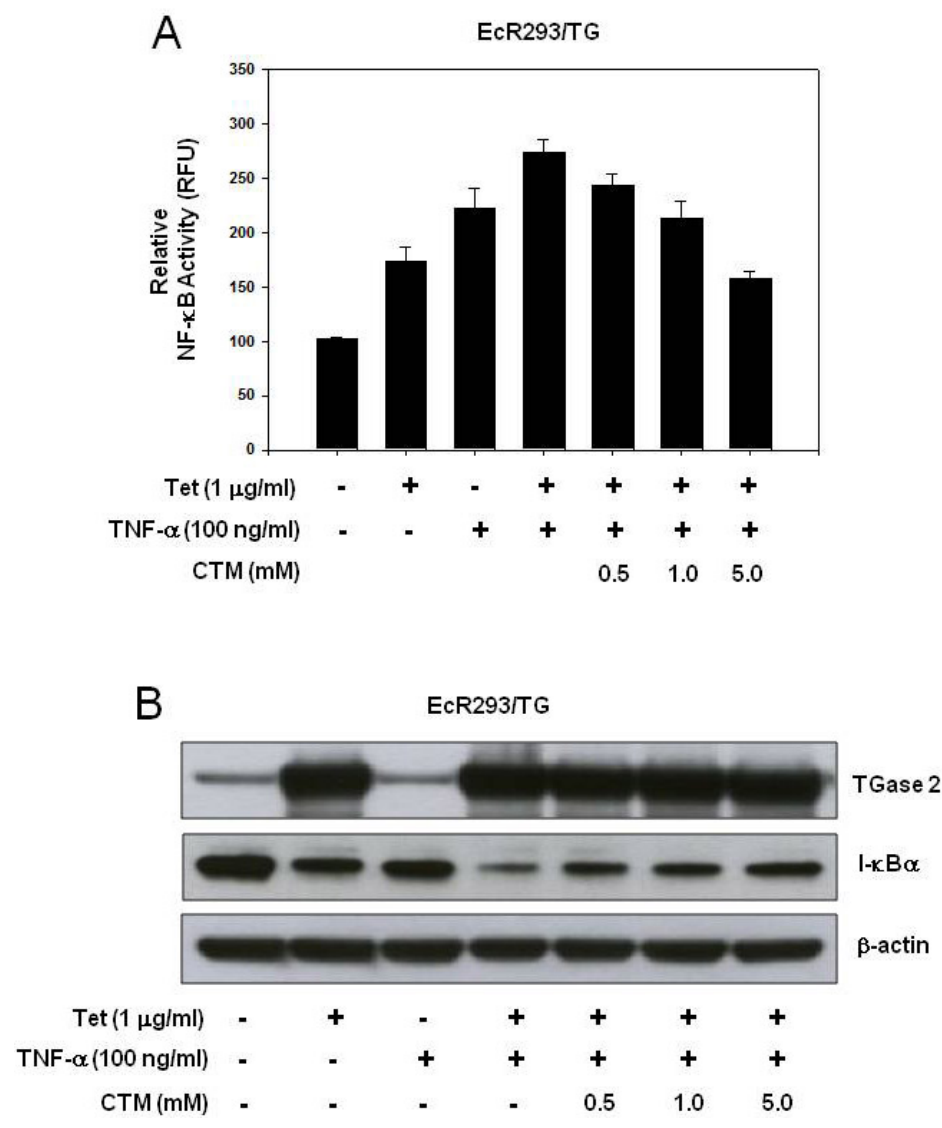

Figure 1. Additive effect of TGase 2 on TNF- $\alpha$ mediated NF- $\kappa B$ activation. (a) SEAP reporter assay using EcR293/TG cells. Cystamine (CTM) was treated in three different concentrations $(0.5,1,5 \mathrm{mM})$ for $1 \mathrm{hr}$ before TGase 2 induction, and tetracycline was treated to induce TGase 2 for $18 \mathrm{hrs}$ together with cystamine. After induction, TNF- $\alpha$ (100 ng/ml) was treated for $6 \mathrm{hrs}$. NF$\kappa \mathrm{B}$ activity induced by TNF- $\alpha$ treatment together with TGase 2 induction was higher than either only with TNF- $\alpha$ or TGase 2 induction. Cystamine reduced the NF- $\kappa$ B activity in a dose dependent manner in TNF- $\alpha$ mediated NF- $\kappa$ B activation. Shown are averages \pm SEM of triplicates. (b) Western blots analysis of TGase 2 and I- $\kappa B \alpha$ in EcR293/TG cells. In the same condition as panel $A$, level of $\mathrm{I}-\kappa \mathrm{B} \alpha$ was recovered by cystamine treatment in a dose-dependent manner. Interestingly, it was rescued decreased I- $\kappa \mathrm{B} \alpha$ by $6 \mathrm{hrs}$ of TNF- $\alpha$ treatment.

5). In the presence of wild-type I- $\mathrm{B} \alpha \alpha, \mathrm{NF}-\kappa \mathrm{B}$ was detected in mainly in the nucleus in TGase 2-induced cells (Figure 5, white arrowhead in WT I- $\kappa \mathrm{B} \alpha$ ). TNF- $\alpha$ treatment combined with TGase 2 induction resulted in prominent translocation of $\mathrm{NF}-\kappa \mathrm{B}$ into the nucleus as compared to TNF- $\alpha$ alone (Figure 5; white arrowhead in I$\kappa \mathrm{B} \alpha$ wild). Expression of TGase 2 targeting site mutants of $\mathrm{I}-\kappa \mathrm{B} \alpha$ resulted in a marked reduction of nuclear NF- $\kappa \mathrm{B}$, and an accumulation of NF- $\kappa \mathrm{B}$ in the cytosol (Figure 5; red arrowheads in $\mathrm{I}-\kappa \mathrm{B} \alpha \mathrm{K} 177 \mathrm{G}$ and Q266G). Expression of

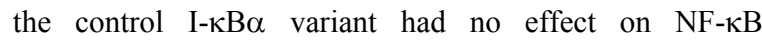
translocation (Figure 5; white arrowhead in I- $\kappa \mathrm{B} \alpha \mathrm{Q} 255 \mathrm{G}$ ).

\section{6. Profound activation of $N F-\kappa B$ in the mouse liver by combined TGase 2 over-expression and TNF- $\alpha$ treatment}

To investigate whether the synergistic activation of $\mathrm{NF}-\kappa \mathrm{B}$ induced in cultured cells by TGase 2 and TNF- $\alpha$ also occurred in vivo, TGase 2 over-expression in mice was achieved by tail vein injection of an adenovirus vector expressing TGase 2 (Adeno/TG2) (Figure 6). Hepatocytes isolated from mice infected with Adeno/TG2 exhibited dramatically elevated levels of TGase 2 expression. Twenty-four hrs after injection of Adeno/TG2, mice were treated with TNF- $\alpha$ through tail vein injection. Five days (120 hrs) after TNF- $\alpha$ treatment, liver tissue was isolated and examined for gross morphology and expression of NF$\kappa \mathrm{B}$. In TGase 2 over-expressing mice, tissue swelling was evident, and there were substantially increased numbers of $\mathrm{NF}-\kappa \mathrm{B}$ positive hepatocytes, whereas liver tissue from control mice was normal in appearance and there was no increase in NF- $\mathrm{\kappa B}$ positive hepatocytes (data not shown). Immunoblot analysis showed that TGase 2 expression was sustained over the period of $120 \mathrm{hrs}$ after TNF- $\alpha$ treatment (Figure 6A). NF- $\kappa \mathrm{B}$ activity was increased approximately 3 -fold by the combination of TGase 2 overexpression and TNF- $\alpha$ treatment (as compared to TNF- $\alpha$ alone); NF- $\kappa \mathrm{B}$ activity induced by TNF- $\alpha$ alone was increased by approximately $50 \%$ over untreated animals (Figure 6B). Cox-2 expression was increased approximately 4-fold in 

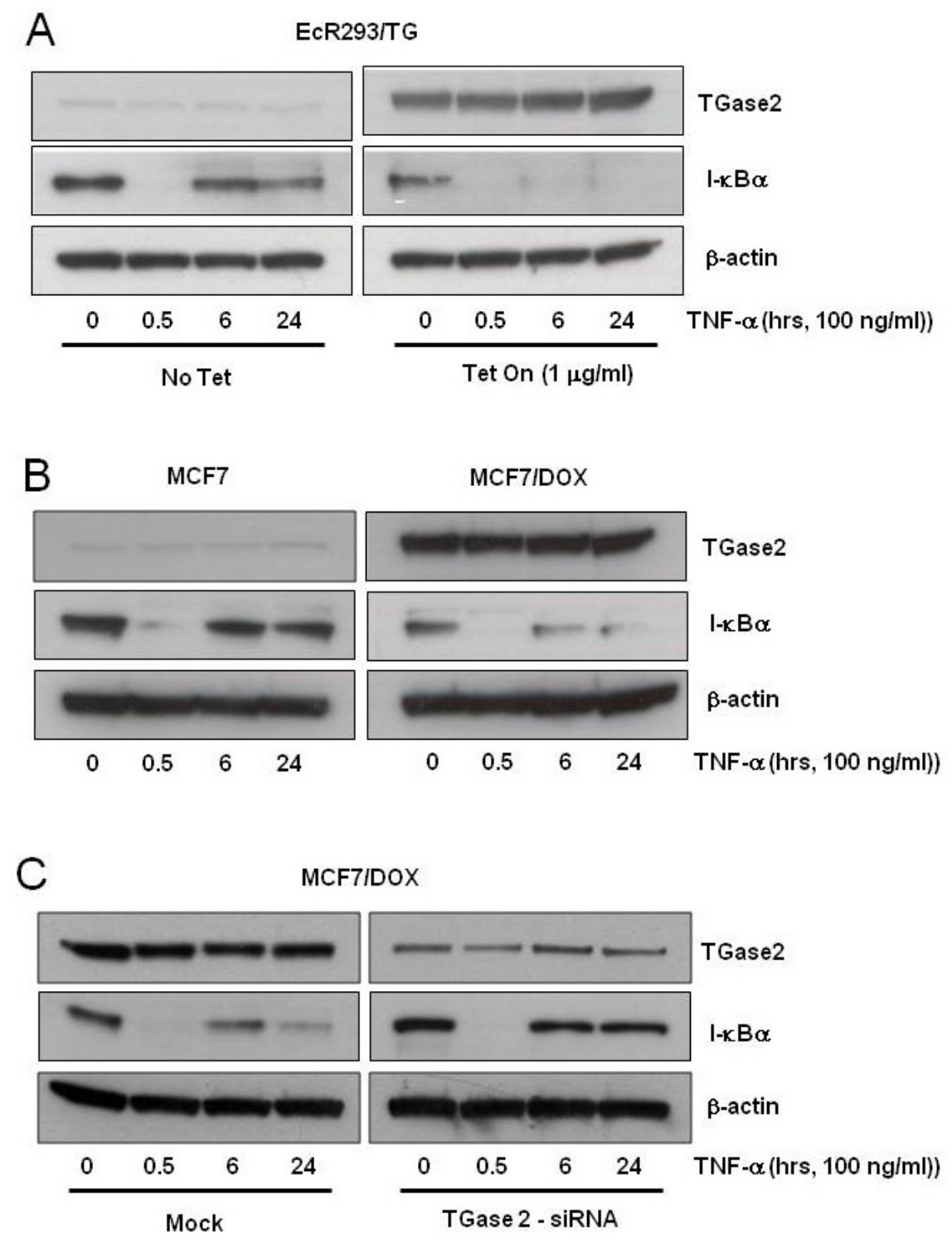

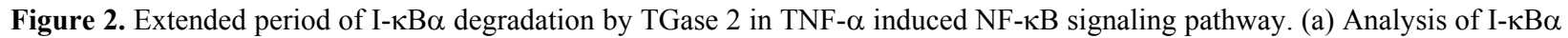
by western blot of cytoplasmic fractions in EcR293/TG cells after treatment of TNF- $\alpha$ (100 ng/ml). In the condition of low

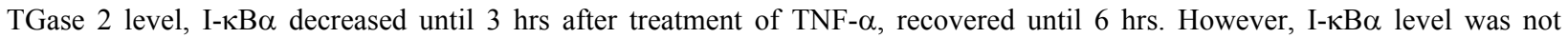
recovered even in $24 \mathrm{hrs}$ after TNF- $\alpha$ treatment in the group with TGase 2 induction. (b and c) Analysis of I- $\kappa \mathrm{B} \alpha$ regulation by TNF- $\alpha$ and TGase 2 in breast cancer cells. MCF-7/DOX (Doxorubicin-resistant) expresses higher level of TGase 2 than MCF-7. By TNF- $\alpha$ treatment $(100 \mathrm{ng} / \mathrm{ml})$, I- $\kappa \mathrm{B} \alpha$ level in MCF-7/DOX was not recovered as much as in MCF-7 even in $24 \mathrm{hrs,} \mathrm{which}$ inversely correlates with TGase 2 expression. For effect of TGase 2 down-regulation on I- $\kappa \mathrm{B} \alpha$ regulation by TNF- $\alpha$ in MCF7/DOX cells. TGase 2 was down-regulated by treatment of TGase 2 siRNA (200 pmol) for 2 days. I- $\kappa \mathrm{B} \alpha$ level in MCF-7/DOX transfected with TGase 2 siRNA was recovered as much as in MCF-7 in $6 \mathrm{hrs}$ after TNF- $\alpha$ treatment $(100 \mathrm{ng} / \mathrm{ml})$.

the combined treatment group (Adeno/TG2 + TNF- $\alpha$ ), while TNF- $\alpha$ alone resulted in a $50 \%$ increase (Figure $6 \mathrm{~A}$ ).

\section{DISCUSSION}

The recent demonstration that TGase 2 plays a critical role in NF- $\mathrm{KB}$ activation in the absence of IKK activation was a significant advance in our understanding of the biological role of TGase $2(11,25)$. NF- $\kappa \mathrm{B}$ is an important component of inflammatory processes and cancer promotion; thus, the involvement of TGase 2 in NF-кB activation could be an important clue to the molecular mechanisms underlying disease etiology. Previously, we demonstrated that specific glutamine and lysine residues at positions 177 and 266 of $\mathrm{I}-\kappa \mathrm{B} \alpha$ are involved in protein cross-linking by TGase 2 (7). We were interested in whether TGase 2 had an additive effect on NF- $\kappa B$ activation in combination with the canonical TNF- $\alpha$ 

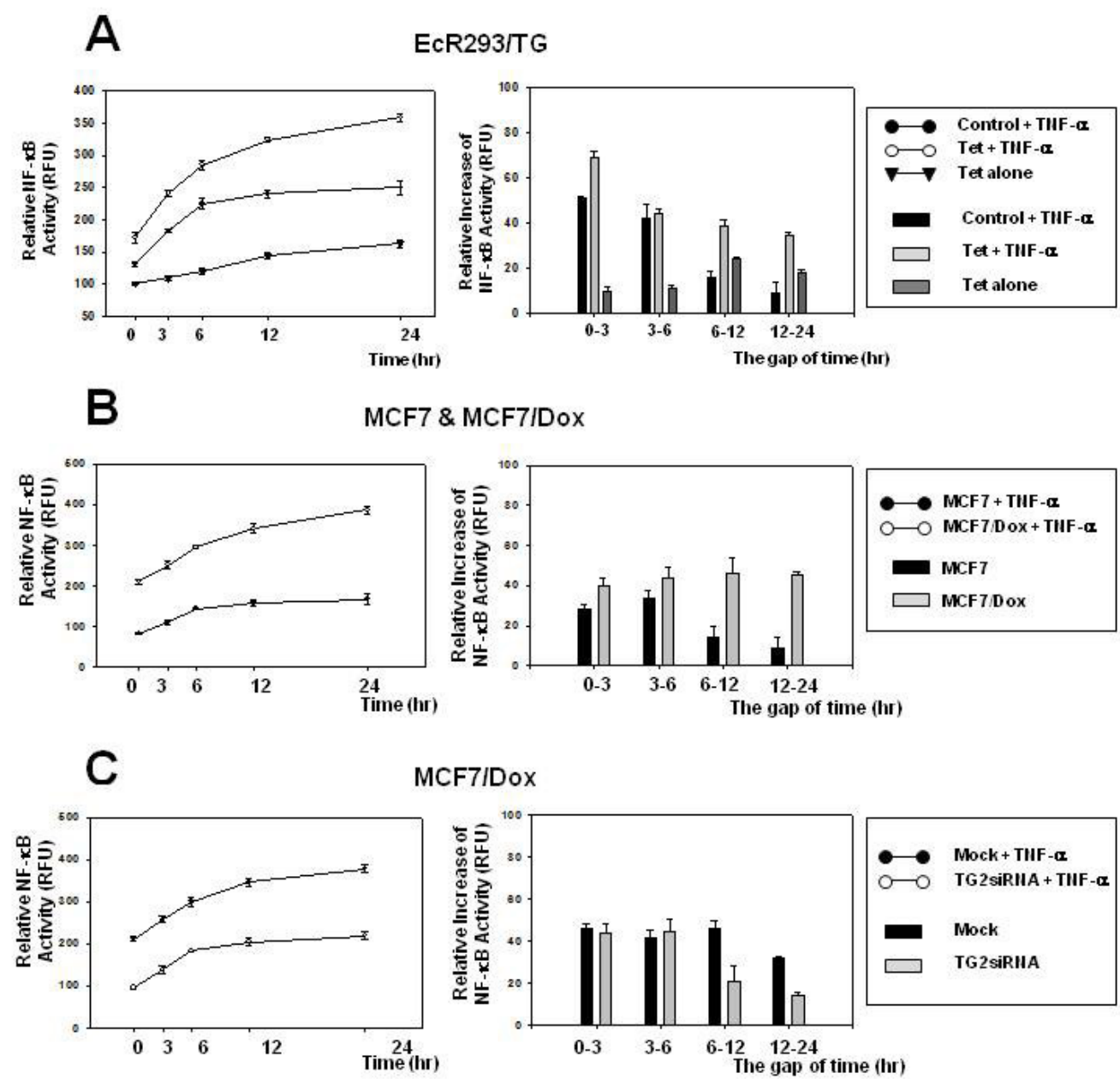

MCF7IDox
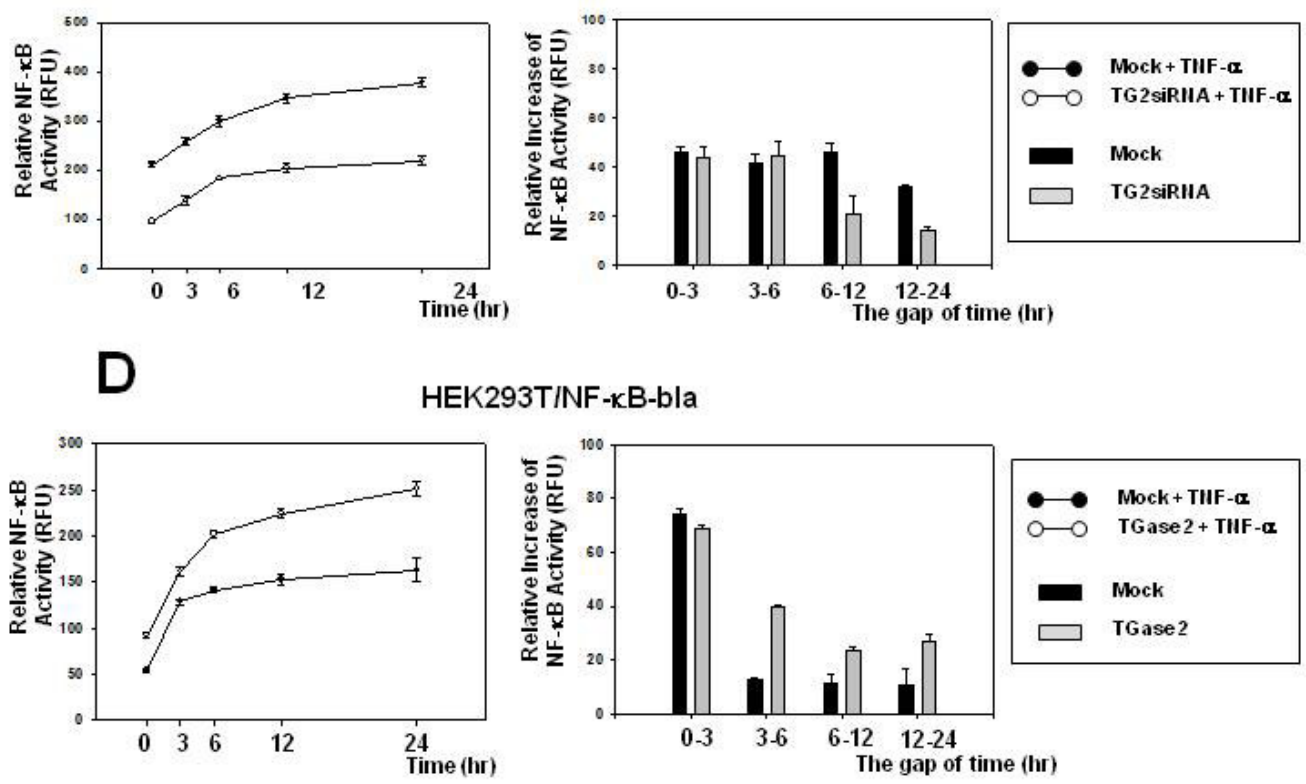

HEK293T/NF-kB-bla

Figure 3. The elongate effect of TGase 2 on TNF- $\alpha$ mediated NF- $\kappa B$ activation. TGase 2 transfection showed elongate effect on TNF- $\alpha$ mediated NF- $\kappa$ B activation in a time dependent manner in the various cell lines. By TNF- $\alpha$ treatment, maintenance of TGase 2 induced NF- $\mathrm{BB}$ activation longer than low level of TGase 2 in the various cell lines. Shown are averages \pm SEM of triplicates. The relative increase of NF- $\kappa B$ activity was measured between the interval times. (a) NF- $\kappa \mathrm{B}$ reporter gene was transfected to 293EcR/TG cell line. After transfection for $24 \mathrm{hrs}$, TGase 2 induction for $24 \mathrm{hrs}$ by tetracycline treatment and TNF- $\alpha$ (100 ng/ml) treated for $24 \mathrm{hrs}$. (b) NF- $\mathrm{kB}$ reporter gene was transfected to MCF7 and MCF7/Dox cell line. After transfection for $24 \mathrm{hrs}$, TNF- $\alpha(100 \mathrm{ng} / \mathrm{ml})$ treated for $24 \mathrm{hrs}$. (c) After MCF7/Dox cells treated by siRNA of TGase 2 for $24 \mathrm{hrs,}$ pNF- $\kappa B-S E A P$ was transfected to the cell line for $24 \mathrm{hrs}$. The treatment time and dose of TNF- $\alpha$ were same as panel A. NF- $\kappa B$ activity induced by TNF- $\alpha$ treatment together with TGase 2-siRNA was lower than only with TNF- $\alpha$. (d) $\beta$-lactamase reporter assay using HEK293T/NF- $\kappa$ B-bla cells. Cells were transfected with TGase $2(1 \mu \mathrm{g})$ for $24 \mathrm{hrs}$, and were treated for 24 hours with TNF- $\alpha(100 \mathrm{ng} / \mathrm{ml})$. Tet, tetracycline. 


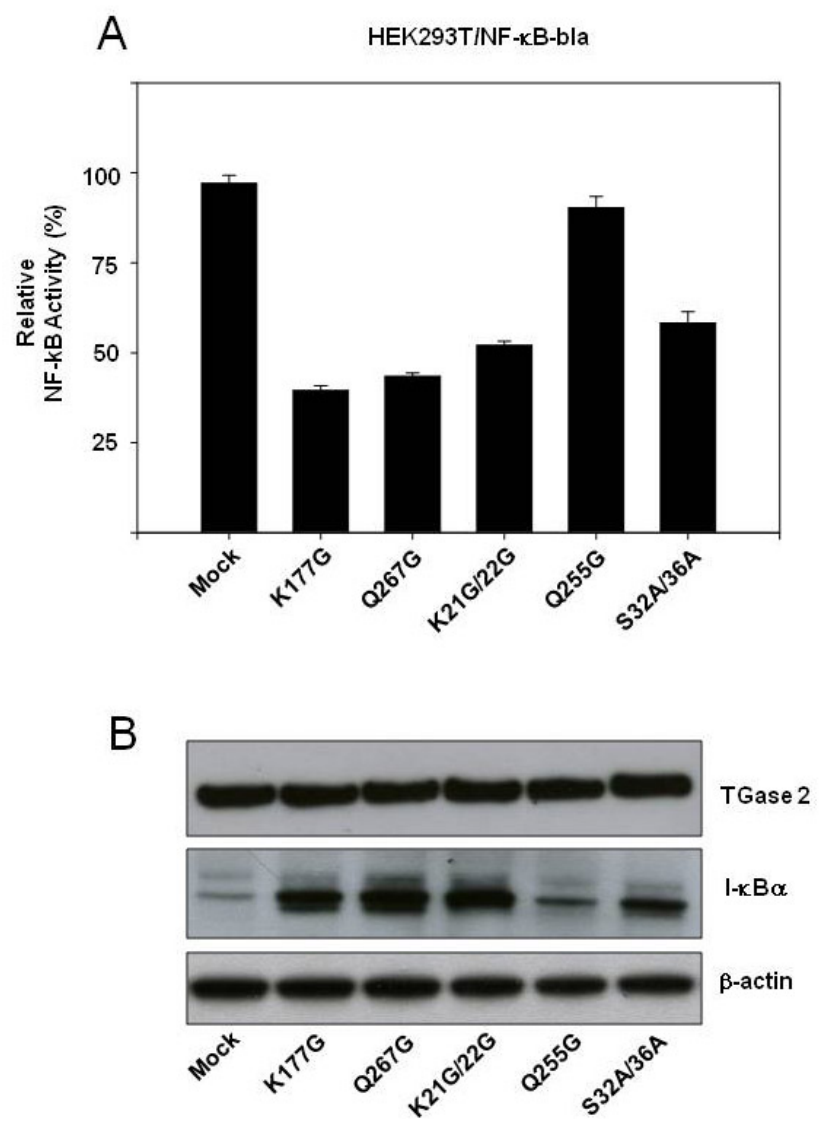

Figure 4. Reversal of TNF- $\alpha$ mediated NF- $\kappa B$ activation by I- $\kappa B \alpha$ mutants at TGase 2 targeting sites. $\beta$-lactamase reporter assay

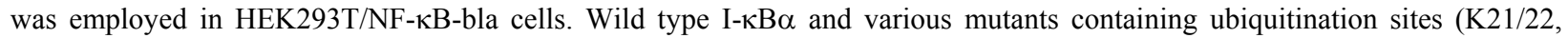
phosphorylation sites by IKK, or cross-link sites by TGase 2 were transfected to HEK293T/NF- $\kappa$ B-bla cells. After 48 hrs transfection, TNF- $\alpha$ was treated for 6 hrs. Ubiquitination and phosphorylation mutants inhibited TNF- $\alpha$ mediated NF- $\kappa B$ activation about $40 \%$. However, mutants at cross-link sites inhibited NF- $\mathrm{KB}$ up to $60 \%$ while random mutant at Q255 showed no

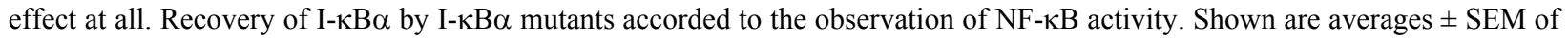
triplicates.

pathway, given the fact that TNF- $\alpha$ can induce TGase 2 expression (23). Here, we showed that TGase 2 expression results in constitutive TNF- $\alpha$-mediated activation of NF$\kappa \mathrm{B}$, and that TGase 2 expression activates $\mathrm{NF}-\kappa \mathrm{B}$ in the absence of IKK activation. Expression of TGase 2 targeting site mutants of $\mathrm{I}-\mathrm{\kappa} \mathrm{B} \alpha$, in which the TGase 2 cross-linking residues were mutated, restored free I- $\kappa \mathrm{B} \alpha$ levels by up to $60 \%$ in the cytosol in response to TNF- $\alpha$. In cells that overexpressed TGase 2, TNF- $\alpha$ treatment resulted in a tremendous increase in NF- $\mathrm{BB}$ activity for up to $24 \mathrm{hrs}$, whereas in control cells that did not overexpress TGase 2, complete recovery was achieved within 6 hrs. These results suggest that increased expression of TGase 2 escalates NF$\kappa \mathrm{B}$ activity for prolonged periods of time, which may exacerbate inflammation and disease processes (Figure 7).

\subsection{TGase 2 expression is increased in inflammatory diseases and cancers}

Increased TGase 2 expression has been reported in many inflammatory diseases, including inflammatory myopathies (13), Celiac disease (14), rheumatoid arthritis
(15), SIV encephalitis (16), and allergic conjunctivitis (17). Abnormally high levels of TGase 2 expression have also been reported in some cancers such as lung cancer (18), breast cancer $(11,19)$, hepatoblastoma (20), pancreatic cancer (21) and glioblastoma (22). The mechanism of induction of TGase 2 expression in these pathological states is unclear. TGase 2 expression can be induced by TNF- $\alpha$ signaling (23), and TGase 2 can be induced by various stresses, including oxidative stress (29), UV (30), calcium influx in response to calcium ionophore (31) or maitotoxin (32), retinoic acid (RA) (33), glutamate (34), and viral infection (16). However, the induction of TGase under these conditions is normalized within a short time. Epigenetic factors have been implicated in the constitutive activation of TGase 2 expression. TGase 2 expression can be induced by demethylation of specific regions of the TGM2 promoter $(35,36,37)$. This induction of TGase 2 results in constitutive $\mathrm{NF}-\kappa \mathrm{B}$ activation associated with drug resistance in breast, ovarian, and lung cancers (38). Relatively higher sensitivity to cisplatin is observed in the TGM2 promoter-methylated cell lines HCC-95 and HCC- 

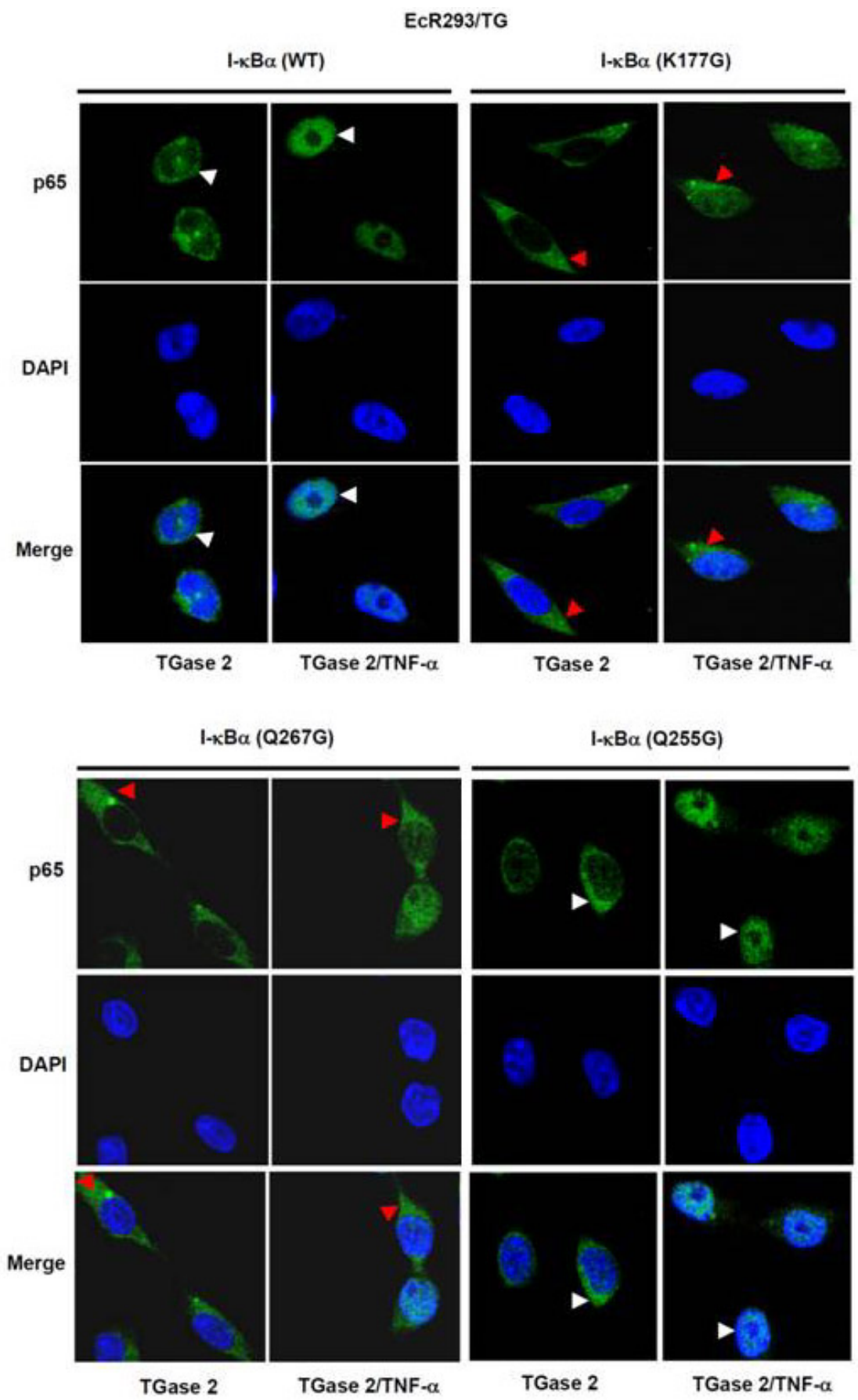

Figure 5. Inhibition of TNF- $\alpha$ mediated NF- $\kappa B$ translocation by I- $\kappa \mathrm{B} \alpha$ mutants at TGase 2 targeting sites. Immunocytochemical staining of NF- $\mathrm{KB}$ using anti-p65 antibody was performed in EcR293/TG cells. Cells were transfected with wild type (WT) or mutant I- $\kappa \mathrm{B} \alpha$ s at TGase 2 targeting sites including K177 and Q266. Mutant at Q255 was used as a negative control. After the 24 hrs, all groups of cells were treated with $1 \mu \mathrm{g} / \mathrm{ml}$ of tetracycline to induce TGase 2 for $24 \mathrm{hrs}$. Following to the induction, cells were treated with or without TNF- $\alpha(100 \mathrm{ng} / \mathrm{ml})$ for $2 \mathrm{hrs}$. Some NF- $\kappa$ B was detected in nucleus by TGase 2 induction (white arrowhead in I- $\kappa \mathrm{B} \alpha(\mathrm{WT}))$. TNF- $\alpha$ treatment with TGase 2 induction showed strong NF- $\kappa \mathrm{B}$ translocation in nucleus than TNF- $\alpha$ alone (white arrowhead in I- $\mathrm{KB} \alpha(\mathrm{WT})$ ). I- $\kappa \mathrm{B} \alpha$ mutants containing TGase cross-linking sites markedly reduced NF- $\mathrm{B}$ translocation to nucleus, which resulted in increase of $\mathrm{NF}-\kappa \mathrm{B}$ detection in the cytosol (red arrowheads in $\mathrm{I}-\mathrm{\kappa B} \alpha(\mathrm{K} 177 \mathrm{G})$ and $(\mathrm{Q} 266 \mathrm{G})$ ). A randomly selected mutant at C-teminus of I- $\mathrm{KB} \alpha$ shows no effect on NF- $\kappa \mathrm{B}$ translocation (white arrowhead in I$\kappa \mathrm{B} \alpha(\mathrm{Q} 255 \mathrm{G}))$. 
A
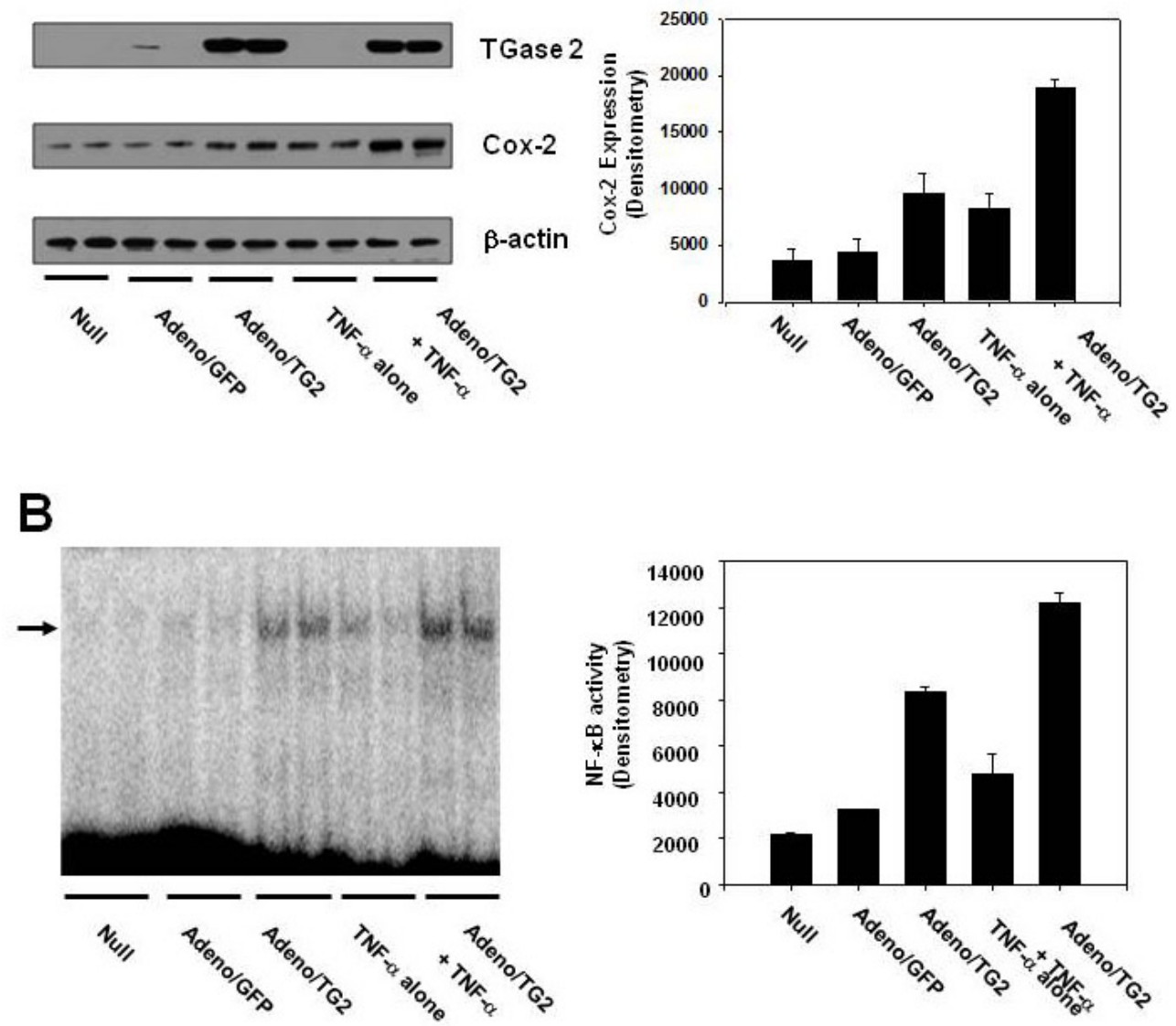

Figure 6. TGase 2 induction using adenovirus system extends TNF- $\alpha$ induced NF- $\kappa$ B activity in vivo. (a) 120 hrs after TNF- $\alpha$ treatment following to Adeno/TG2 or mock viral vector infection, the liver tissues from mice were homogenized, and western blotting was performed against TGase 2 and cyclooxigenase 2 (Cox-2). The double treatment group (Adeno/TG2 + TNF- $\alpha$ ) showed the highest expressional level of Cox-2. (b) For EMSA assay, nuclear extracts corresponding to the analyses above were incubated with a ${ }^{32} \mathrm{P}$-labeled NF- $\kappa \mathrm{B}$ probe, followed by electrophoresis and autoradiography. NF- $\mathrm{BB}$ activity was quantitated using densitometry. TNF- $\alpha$ only treatment group showed decreased NF- $\kappa B$ activity that is less than adeno/TGase 2 group. However, the double treatment group showed two times higher NF- $\kappa$ B activity than TNF- $\alpha$ only treatment group showed.

1588 as compared to TGM2-expressing cell lines (NCIH1299 and HCC-1195). The results of down-regulation and over-expression of TGM2 in non-small cell lung carcinoma (NSCLC) cells also suggest a positive correlation between cisplatin sensitivity and TGM2 inhibition (35).

\subsection{The prolongation effect of TGase 2 on TNF- $\alpha$ - induced NF- $\kappa B$ activation \\ TGase 2 catalyzes protein cross-linking, and TGase 2 has been recognized as an important factor in matrix formation and cell adhesion. However, the function of TGase 2 in inflammation etiology is not clear. TGase 2 activation results in depletion of free $\mathrm{I}-\kappa \mathrm{B} \alpha$ through protein polymerization. Here, we demonstrated that induction of TGase 2 reduces the levels of free I- $\kappa \mathrm{B} \alpha$ in the cytosol, and this depletion correlates with NF- $\kappa \mathrm{B}$ activation (Figs. 1 and $2)$. We therefore investigated whether TGase 2 over- expression prolongs the activation of NF- $\mathrm{KB}$ through a}

canonical inducer of inflammation. Here, we used TNF- $\alpha$ treatment as an inflammatory stress. Interestingly, TNF- $\alpha-$ induced NF- $\mathrm{KB}$ activation gradually increased as TGase 2 expression increased. Moreover, cells in which TGase 2 was over-expressed exhibited sustained NF- $\kappa \mathrm{B}$ activation in response to TNF- $\alpha$ as compared control cells (Figure 3 ). The levels of $\mathrm{I}-\kappa \mathrm{B} \alpha$ in un-induced cells that did not overexpress TGase 2 recovered to normal levels within 30 min to $1 \mathrm{hr}$ of TNF- $\alpha$ treatment (Figure 2) (9). Surprisingly, I- $\kappa \mathrm{B} \alpha$ levels failed to recover from TNF- $\alpha$ treatment even after $24 \mathrm{hrs}$ in the presence of TGase 2 expression (Figure 2). This is an intriguing finding because increased TGase 2 expression is often reported in many inflammatory diseases. In addition, TGase 2 expression has been reported in diseases with associated inflammation such as Parkinson's disease, Alzheimer's disease, Huntington's disease, diabetes mellitus, atherosclerosis and cancers. We cannot determine based on the current results 


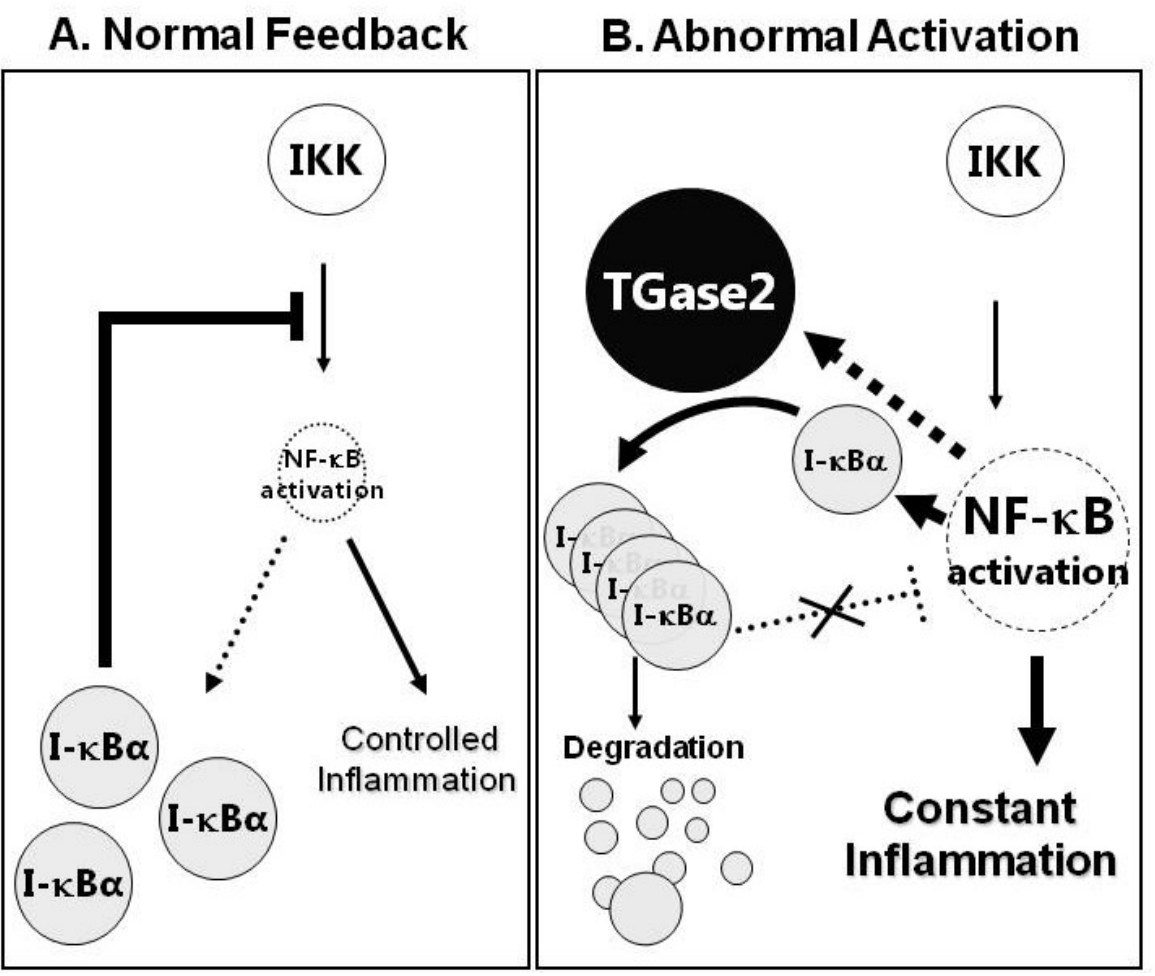

Figure 7. Proposed role of TGase 2 in NF- $\kappa B$ activation (Ouroboros theory of NF- $\kappa B$ activation). In normal condition, NF- $\kappa B$ activation by IKK signaling has feedback mechanism by induced I- $\kappa B \alpha$. Although TGase 2 can be also induced by NF- $\kappa B$, the induced I- $\mathrm{KB} \alpha$ may be enough to block the pathway in normal condition. However, in case of induced TGase 2 situation before IKK signaling by epigenetic change, TGase 2 appears to deplete I- $\kappa \mathrm{B} \alpha$ efficiently, which results in elongated period of IKK dependent NF- $\mathrm{KB}$ activation.

whether increased TGase 2 expression leads to a constitutive inflammatory state or constitutive activation of inflammatory signals. However, the results suggest that once TGase 2 expression is increased, it may be sufficient to exacerbate TNF- $\alpha$ induced inflammation.

\subsection{Reduction of TNF- $\alpha$ induced NF- $\kappa B$ activation by TGase 2 inhibition \\ Inhibition of TGase 2 by CTM reversed the} kinetics of $\mathrm{I}-\kappa \mathrm{B} \alpha$ recovery in the presence of TNF- $\alpha$ in a dose-dependent manner, resulting in a reduction of TNF- $\alpha$ induced NF- $\kappa \mathrm{B}$ activity (Figure $1 \mathrm{~A}$ ). Previously we identified the amino acid residues of $\mathrm{I}-\kappa \mathrm{B} \alpha$ that are targeted by TGase 2 (7). Transient expression of dominant negative mutants of I- $\kappa \mathrm{B} \alpha$ in which these TGase 2 crosslinking sites, namely lysine 177 and glutamines 266 and 267 , were mutated, reversed NF- $\kappa B$ activity to $40 \%$ of that seen in the presence of TNF- $\alpha$, whereas expression of wildtype I- $\kappa \mathrm{B} \alpha$ reduced $\mathrm{NF}-\kappa \mathrm{B}$ activity by only $10 \%$ (Figure 4). These results suggest that TGase 2 in involved in the depletion of $\mathrm{I}-\kappa \mathrm{B} \alpha$ in response to activation of a canonical pathway of NF- $\kappa \mathrm{B}$ activation. In other words, TGase 2 may be responsible for up to $50 \%$ of the NF- $\mathrm{BB}$ activity induced by TNF- $\alpha$. These results were confirmed by immunoblot analysis. Furthermore, the vast majority of NF- $\mathrm{BB}$ (p65) localized to the nucleus following TNF- $\alpha$ treatment in the presence of wild type $\mathrm{I}-\kappa \mathrm{B} \alpha$, co-localizing precisely with
DAPI-stained nuclei (Figure 5). In contrast, in the presence of the TGase 2 targeting site mutants of I- $\kappa \mathrm{B} \alpha$ (K177G and Q266G), approximately $50 \%$ of cellular NF- $\kappa \mathrm{B}$ remained in the cytosol after TNF- $\alpha$ treatment (Figure 5).

\subsection{Exacerbation of TNF- $\alpha$-mediated inflammation in the mouse liver by TGase 2 over-expression}

To determine whether the synergistic increase in NF- $\kappa \mathrm{B}$ activation in cultured cells by TGase 2 and TNF- $\alpha$ also occurred in vivo, TGase 2 expression was induced in mice using a recombinant TGase 2-expressing adenoviral vector. Following infection with Adeno/TG2, TNF- $\alpha$ was injected via the mouse tail vein, and then the inflammatory response in the liver in the presence or absence of TGase 2 over-expression was assessed (Figure 6). TGase 2 levels in hepatocytes were markedly increased $120 \mathrm{hrs}$ after infection. Analysis of liver tissue revealed increased NF- $\mathrm{KB}$ activity as well as Cox-2 expression in Adeno/TG2infected animals after $120 \mathrm{hrs}$ (Figure 6). Importantly, NF$\kappa \mathrm{B}$ activity was dramatically increased and markedly sustained for over $120 \mathrm{hrs}$ in the livers of Adeno/TG2infected animals treated with TNF- $\alpha$, whereas livers from control animals treated with TNF- $\alpha$ alone exhibited less NF- $\kappa \mathrm{B}$ activity than Adeno/TG2-infected animals (Figure 6). TGase-2 and NF- $\kappa B$ were expressed simultaneously within hepatocytes, which suggested that the prolongation of NF- $\kappa \mathrm{B}$ activation was due to TGase 2 expression. These 
results suggest that increased expression of TGase 2 is involved in the progression of inflammatory diseases, and that inhibition of TGase 2 may be a promising intervention for reducing long term inflammation.

\subsection{Model for TGase 2 in NF- $\mathrm{KB}$ activation}

Constitutive NF- $\kappa \mathrm{B}$ activation has been reported in chronic inflammatory diseases, making it a potential target in the development of therapeutics (1). However, constitutive NF- $\kappa \mathrm{B}$ activation is not always accompanied by constitutive $\mathrm{I}-\kappa \mathrm{B} \alpha$ phosphorylation (8). Although several other kinases that deplete free I- $\kappa \mathrm{B} \alpha$ have been identified (1), there are other possible mechanisms of induction of $\mathrm{NF}-\kappa \mathrm{B}$ activity in the absence of $\mathrm{I}-\kappa \mathrm{B} \alpha$ phosphorylation. The PEST sequence (proline $(\mathrm{P})$, glutamic acid $(\mathrm{E})$, serine $(\mathrm{S})$, threonine $(\mathrm{T})$ ) in the $\mathrm{C}$-terminal region of I- $\kappa \mathrm{B} \alpha$ plays a very important role in the rapid turnover of $\mathrm{I}-\mathrm{\kappa B} \alpha$ in the absence of phosphorylation (38). Interestingly, regardless of mechanism, depletion of $\mathrm{I}-\kappa \mathrm{B} \alpha$ is the main cause of NF- $\kappa \mathrm{B}$ activation, as $\mathrm{I}-\kappa \mathrm{B} \alpha$ is the most effective negative regulator of $\mathrm{NF}-\kappa \mathrm{B}(9)$. Thus, the various pathways of NF- $\mathrm{BB}$ activation must work cooperatively to achieve efficient induction of anti-inflammatory genes. It is unclear whether increased TGase 2 expression is due to $\mathrm{NF}-\kappa \mathrm{B}$ activation, or vice versa, in disease states. Here, we showed that increased TGase 2 expression exacerbates TNF- $\alpha$-induced inflammation. Interestingly, constitutive NF- $\kappa \mathrm{B}$ activation often accompanies increased TGase 2 expression in inflammatory diseases such as inflammatory bowel disease, rheumatoid arthritis, and allergic conjunctivitis, as well as certain cancers such as breast cancer and neuroblastoma (11). TGase 2 expression can be induced by various stresses as well as epigenetic modifications such as de-methylation of the TGM2 promoter (35). Here, we demonstrated that TGase 2 induction is required for sustained NF- $\kappa \mathrm{B}$ activation, which in turn delays the resolution of inflammation. We propose an 'Ouroboros theory of NF- $\kappa \mathrm{B}$ activation' (review submitted), in which NF- $\mathrm{B}$ activation induces TGase 2 expression, which in turn exacerbates inflammation (Figure 7). Thus, an inflammatory inducer such as TNF- $\alpha$ may trigger significant activation of $\mathrm{NF}-\kappa \mathrm{B}$, particularly in individuals in which TGase 2 expression is elevated.

\section{ACKNOWLEDGEMENTS}

This work was supported by a research grant (NCC0510270 and NCC0810181) from the National Cancer Center in Korea and by Basic Science Research Program through the National Research Foundation of Korea (NRF) funded by the Ministry of Education, Science and Technology (No.20090086078). We declare that none of the authors have a financial interest related to this work, and none of the authors have any financial support beyond the research grants mentioned above.

\section{REFERENCES}

1. Karin M. Nuclear factor-kappaB in cancer development and progression. Nature 441, 431-436 (2006)
2. Karin, M, Greten, FR. NF-kappaB: linking inflammation and immunity to cancer development and progression. Nat. Rev. Immunol. 5, 749-759 (2005)

3. Watanabe T, Jono H, Han J, Lim DJ, Li JD. Synergistic activation of NF-kappaB by nontypeable Haemophilus influenzae and tumor necrosis factor alpha. Proc. Natl. Acad. Sci. USA. 101, 3563-3568 (2004)

4. Devary Y, Rosette C, DiDonato JA, Karin M. NFkappaB activation by ultraviolet light not dependent on a nuclear signal. Science 261, 1442-1445 (1993)

5. Schieven GL, Kirihara JM, Myers DE, Ledbetter JA, Uckun FM. Reactive oxygen intermediates activate NFkappaB in a tyrosine kinase-dependent mechanism and in combination with vanadate activate the p56lck and p59fyn tyrosine kinases in human lymphocytes. Blood 82, 12121220 (1993)

6. Poltorak A, He X, Smirnova I, Liu MY, Van Huffel C, Du X, Birdwell D, Alejos E, Silva M, Galanos C, Freudenberg M, Ricciardi-Castagnoli P, Layton B, Beutler B. Defective LPS signaling in $\mathrm{C} 3 \mathrm{H} / \mathrm{HeJ}$ and C57BL/10ScCr mice: mutations in Tlr4 gene. Science 282, 2085-2088 (1998)

7. Park SS, Kim JM, Kim DS, Kim IH, Kim SY. Transglutaminase 2 mediates polymer formation of IkappaBalpha through C-terminal glutamine cluster. J. Biol. Chem. 281, 34965-34972 (2006)

8. Tergaonkar V, Bottero V, Ikawa M, Li Q, Verma IM. IkappaB kinase-independent IkappaBalpha degradation pathway: functional NF-kappaB activity and implications for cancer therapy. Mol. Cell. Biol. 23, 8070-8083 (2003)

9. Hoffmann A, Levchenko A, Scott ML, Baltimore D. The IkappaB-NF-kappaB signaling module: temporal control and selective gene activation. Science 298, 1241-1245 (2002)

10. Kim SY. New target against inflammatory diseases: transglutaminase 2. Arch. Immunol. Ther. Exp. (Warsz) 52, 332-337 (2004)

11. Kim SY. Transglutaminase 2 in inflammation. Front. Biosci. 11, 3026-3035 (2006)

12. Choi YC, Park GT, Kim TS, Sunwoo IN, Steinert PM, Kim SY. Sporadic inclusion body myositis correlates with increased expression and cross-linking by transglutaminases 1 and 2. J. Biol. Chem. 275, 8703-8710 (2000)

13. Choi YC, Kim TS, Kim SY. Increase in transglutaminase 2 in idiopathic inflammatory myopathies. Eur. Neurol. 51, 10-14 (2004)

14. Dieterich W, Ehnis T, Bauer M, Donner P, Volta U, Riecken EO, Schuppan D. Identification of tissue 
transglutaminase as the autoantigen of celiac disease. Nat. Med. 3, 797-801 (1997)

15. Weinberg JB, Pippen AM, Greenberg CS. Extravascular fibrin formation and dissolution in synovial tissue of patients with osteoarthritis and rheumatoid arthritis. Arthritis. Rheum. 34, 996-1005 (1991)

16. Roberts ES, Zandonatti MA, Watry DD, Madden LF, Henriksen SJ, Taffe MA, Fox HS. Induction of pathogenic sets of genes in macrophages and neurons in NeuroAIDS. Am. J. Pathol. 162, 2041-2057 (2003)

17. Sohn J, Kim TI, Yoon YH, Kim JY, Kim SY. Novel transglutaminase inhibitors reverse the inflammation of allergic conjunctivitis. J. Clin. Invest. 111, 121-128 (2003)

18. Han JA, Park SC. Reduction of transglutaminase 2 expression is associated with an induction of drug sensitivity in the PC-14 human lung cancer cell line. $J$. Cancer. Res. Clin. Oncol. 125, 89-95 (1999)

19. Mehta K. High levels of transglutaminase expression in doxorubicin-resistant human breast carcinoma cells. Int. $J$. Cancer. 58, 400-406 (1994)

20. Suto N, Ikura K, Sasaki R. Expression induced by interleukin- 6 of tissue-type transglutaminase in human hepatoblastoma HepG2 cells. J. Biol. Chem. 268, 74697473 (1993)

21. Iacobuzio-Donahue CA, Ashfaq R, Maitra A, Adsay NV, Shen-Ong GL, Berg K, Hollingsworth MA, Cameron JL, Yeo CJ, Kern SE, Goggins M, Hruban RH. Highly expressed genes in pancreatic ductal adenocarcinomas: a comprehensive characterization and comparison of the transcription profiles obtained from three major technologies. Cancer. Res. 63, 8614-8622 (2003)

22. Zhang R, Tremblay TL, McDermid A, Thibault P, Stanimirovic D. Identification of differentially expressed proteins in human glioblastoma cell lines and tumors. Glia. 42, 194-208 (2003)

23. Kuncio GS, Tsyganskaya MJ, Zhu SL, Liu LNagy, Thomazy V, Davies PJ, Zern MA. TNF-alpha modulates expression of the tissue transglutaminase gene in liver cells. Am. J. Physiol. 274, G240-245 (1998)

24. Cordella-Miele E, Miele L, Mukherjee AB. A novel transglutaminase mediated post-translational modification of phospholipase A2 dramatically increases its catalytic activity. J. Biol. Chem. 265, 17180-17188 (1990)

25. Lee J, Kim YS, Choi DH, Bang MS, Han TR, Joh TH, Kim SY. Transglutaminase 2 induces nuclear factorkappaB activation via a novel pathway in BV-2 microglia. J. Biol. Chem. 279 (51), 53725-53735 (2004)

26. Suh GY, Ham HS, Lee SH, Choi JC, Koh WJ, Kim SY, Lee J, Han J, Kim HP, Choi, AM. and Kwon, OJ. A Peptide with anti-transglutaminase activity decreases lipopolysaccharide-induced lung inflammation in mice. Exp. Lung. Res. 32, 43-53 (2006)

27. Yuan L, Siegel M, Choi K, Khosla C, Miller CR, Jackson EN, Piwnica-Worms D, Rich KM. Transglutaminase 2 inhibitor, KCC009, disrupts fibronectin assembly in the extracellular matrix and sensitizes orthotopic glioblastomas to chemotherapy. Oncogene 26, 2563-2573 (2007)

28. Herman JF, Mangala LS, Mehta K. Implications of increased tissue transglutaminase (TG2) expression in drug-resistant breast cancer (MCF-7) cells. Oncogene 25, 3049-3058 (2006)

29. Fujita K, Shibayama K, Yamauchi M, Kato T, Ando M, Takahashi H, Iritani K, Yoshimoto N, Nagata Y. Alteration of enzymatic activities implicating neuronal degeneration in the spinal cord of the motor neuron degeneration mouse during postnatal development. Neurochem. Res. 23, 557$562(1998)$

30. Gross SR, Balklava Z, Griffin M. Importance of tissue transgluta minase in repair of extracellular matrices and cell death of dermal fibroblasts after exposure to a solarium ultraviolet A source. J. Invest. Dermatol. 121, 412-423 (2003)

31. Lorand L, Weissmann LB, Epel DL, Bruner-Lorand J. Role of the intrinsic transglutaminase in the $\mathrm{Ca} 2+$-mediated crosslinking of erythrocyte proteins. Proc. Natl. Acad. Sci. USA. 73, 4479-4481 (1976)

32. Lesort M, Attanavanich K, Zhang J, Johnson GV. Distinct nuclear localization and activity of tissue transglutaminase. J. Biol. Chem. 273, 11991-11994 (1998)

33. Scott KF, Meyskens Jr FL, Russell DH. Retinoids increase transgl utaminase activity and inhibit ornithine decarboxylase activity in Chinese hamster ovary cells and in melanoma cells stimulated to differentiate. Proc. Natl. Acad. Sci. USA.79, 4093-4097 (1982)

34. Caccamo D, Campisi A, Currò M, Aguennouz M, Volti G Li, Avola R, Ientile R. Nuclear factor kappaB activation is associated with glutamate-evoked tissue transglutaminase up-regulation in primary astrocyte cultures. J. Neurosci. Res. 82, 858-865 (2005)

35. Park KS, Kim HK, Lee JH, Choi YB, Park SY, Yang $\mathrm{SH}$, Kim SY, Hong KM. Transglutaminase 2 as a cisplatin resistance marker in non-small cell lung cancer. J. Cancer Res. Clin. Oncol. 136, 493-502 (2010)

36. Ai L, Kim WJ, Demircan B, Dyer LM, Bray KJ, SkehanR R, Massoll NA, Brown KD. The transglutaminase 2 gene (TGM2), a potential molecular marker for chemotherapeutic drug sensitivity, is epigenetically silenced in breast cancer. Carcinogenesis 29 (3), 510-518 (2008)

37. Cacciamani T, Virgili S, Centurelli M, Bertoli E, 
Eremenko T, Volpe P. Specific methylation of the CpG-rich domains in the promoter of the human tissue transglutaminase gene. Gene 297 (1-2), 103-112 (2002)

38. Rogers S, Wells R, Rechsteiner M. Amino acid sequences common to rapidly degraded proteins: the PEST hypothesis. Science 234, 364-368 (1986)

Abbreviations: TGase 2, transglutaminase 2; NF- $\kappa \mathrm{B}$, nuclear factor kappa $\mathrm{B}$; I- $\kappa \mathrm{B} \alpha$.Inhibitor of nuclear factor kappa-B alpha; TNF- $\alpha$, tumor necrosis factor alpha; IKK, I-אB kinase; LPS, Lipopolysaccharide; CTM, cystamine; WT, wild type; Tet, tetracycline.

Key Words: transglutaminase 2, I- $\kappa \mathrm{B} \alpha, \quad \mathrm{NF}-\kappa \mathrm{B}$, inflammation, TNF- $\alpha$, Review

Send correspondence to: Soo-Youl Kim, Jungbalsanro, Ilsandong-gu, Goyang, Kyonggi-do 410-351, Republic of Korea, Tel: 82-31-920-2221, Fax: 82-31-920-2006, E-mail: kimsooyoul@gmail.com

http://www.bioscience.org/current/vol3E.htm 